\title{
GOLLEE 8
}

\section{RESEA R C H}

LI B R A R I E S

AVEIVC

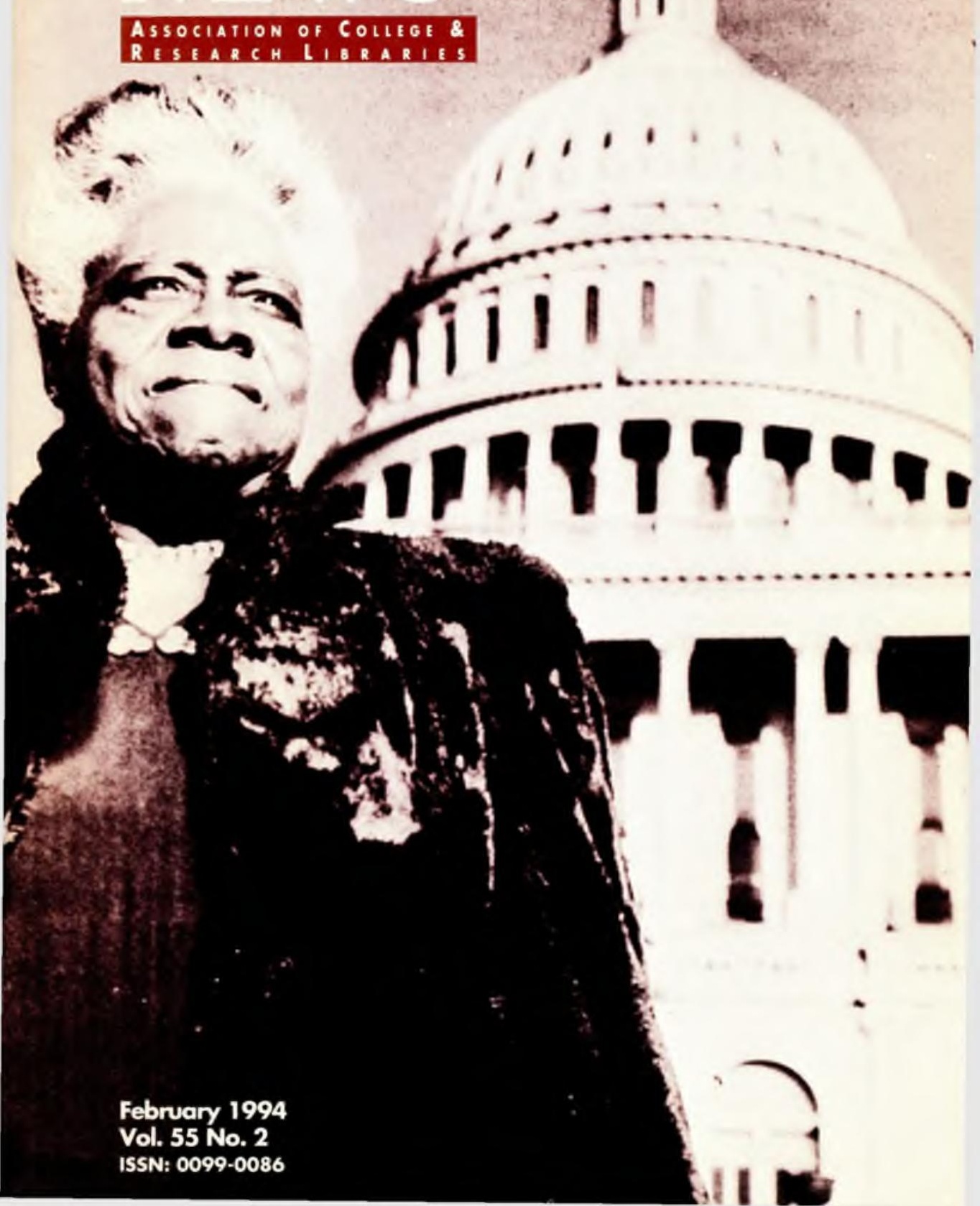




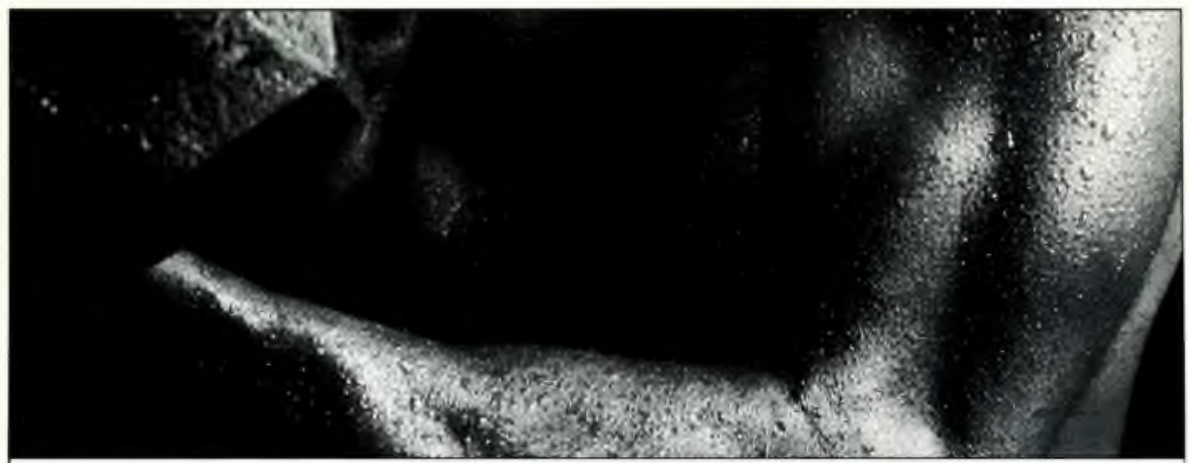

\section{No one pumps up your psychological search capability like PsycINFO!}

$\mathrm{P}$ sycINFO's computerized databases and printed indexes are trusted psychological reference tools backed by 70 years of experience.

Unrivaled in their depth of psychological coverage, they are enriched with literature from an array of related disciplines such as education, medicine, nursing, law, management, and social work. These dynamic resources are continually updated to keep pace with the growth of psychology and the social sciences.

PsycINFO offers a family of products, each tailored to specific research purposes and budgets:

The PsycINFO Online Database contains journal references from 46 countries in over 30 languages and dissertations from U.S. literature, all from 1967-present. It's accessible through commercial online services or direct tape leasing from APA.

PsycLIT contains references from 1974-present, including journals, book chapters, and book records. It offers userfriendly interface, unlimited searches, and is distributed through CD-PLUS, EBSCO, and SilverPlatter for a fixed annual subscription cost. Be sure to ask about our new, special rates for psychology departments... and our free, 30-day trial!

\section{Psychological Abstracts ${ }^{*}$,} the time-honored printed index to psychological and behavioral literature, provides summaries of international
English-language journal articles, book chapters, and books. Available by annual subscription.

ClinPSYC $^{\mathrm{IM}}$ is a specialized CD-ROM database for clinical psychology and behavioral medicine covering 1980present. It is distribured by CD-PLUS and SilverPlatter and is available by annual subscription. Try our 30-day free trial!

For more information on the PsycINFO family of products, call 1-800-374-2722.

PsycINFO

American Psychological Association 750 First Street, NE

Wash., DC 20002-4242 (202) $336-5650$

Fax (202) 336-5633

TDD: (202) 336-6123 Internet: psycinfo@apa.org

\section{PsycINFO - the most comprehensive and authoritative publisher of bibliographic reference sources in psychology}

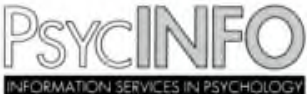




\section{Real customer service.}
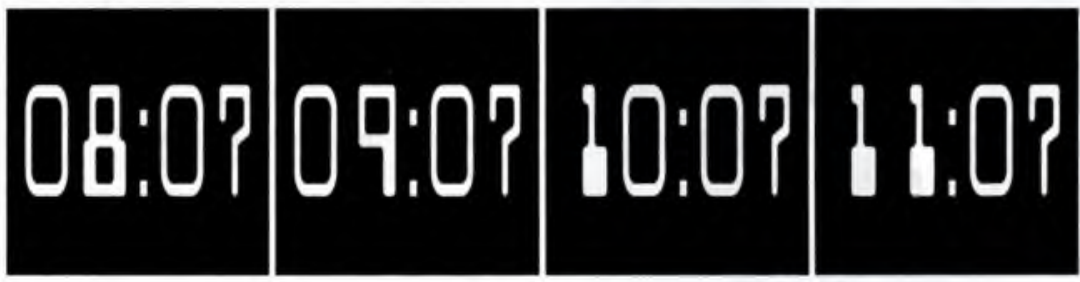

In real time.

Providing the level of personal service we believe in requires being available when our customers need us. So our 11 regional offices in North America are staffed with customer service representatives who are only a phone call away. With at least one regional office located in each of the four major time zones, it's more likely our representatives will be where you need them when you need them - not several hours away.

We believe in providing real customer service in real time.

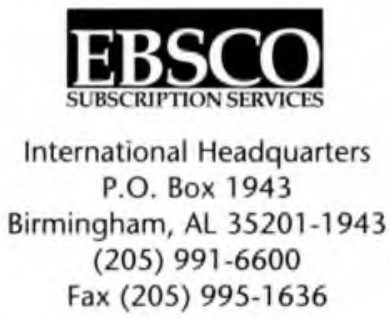

North American offices located in Birmingham, Ala.; Chicago; Dallas; Denver; Los Angeles; Montreal; Red Bank, NI; San Francisco; Tenafly, NI; Toronto; and Washington. Seventeen offices located throughout the rest of the world. 


\section{Colleg $\&$}

RESEAR C H

LI B R A R I E S

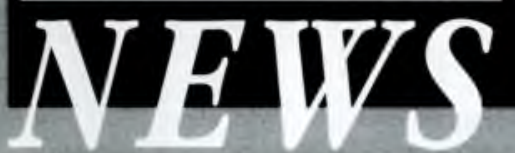

ASSOCIATION OF COLLEE 8

RESEARCHLIBRARIES

\section{FEATURES}

Customer service: The heart of a library

Hardy R. Franklin

Customer feedback-how to get it

Linda $K$. Wallace

64

\section{African studies computer resources}

Patricia S. Kuntz

Indiana builds three African American special collections

Grace Jackson-Brown

\section{Censorship in an academic} ibrary

Susan Podrygula

No food, no drink, no noise

Elaine Clement and Patricia A. Scott

The Way I See It

Books, computers, and the

Pushmi-Pullyu

Merrily E. Taylor

\section{About the cover}

This photo shows Mary McLeod Bethune standing in front of the Capitol Building in Washington, D.C., during her tenure as Special Advisor on Minority Affairs to the Roosevelt Administration. Bethune was born in Mayesville, South Carolina, on July 10, 1875. She attended the Presbyterian Mission School in Mayesville; the Scotia Seminary in Concord, New Hampshire; and Moody Bible Institute in Chicago. She taught at Haines Institute in Georgia, and established a Home for Delinquent Colored Girls in Florida. In 1904 she founded the Daytona Literary and Industrial School for Training Negro Girls (now Bethune-Cookman College), and served as president there from 1904-1942 and 1946-1947. She founded the National Council of Negro Women in 1935, and was director of the Negro Affairs of the National Youth Administration (1935-1943). She was also an honorary general in the Women's Army for $\mathrm{Na}$ tional Defense (WANDS). 
DEPARTMENTS

In the News

\section{News from the Field}

Jurassic Park lives at Utah State University

Mary I. Piette, Robert Morrison and Betty Dance

\section{Letfers}

\section{Washington Hotline}

Carol C. Henderson

\section{Preservation News}

Jane Hedberg

\section{Infernet Reviews}

Sara Amato

\section{New Publications}

George M. Eberbart

\section{Grants}

Acquisitions

People in the News

\section{Advertiser Index}

\section{Classified Advertising}

100

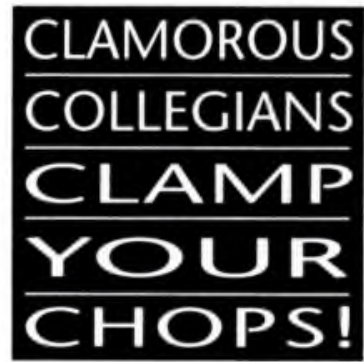

This graphic is part of Pennsylvania State University's campaign to curb food, drink, and noise problems in the libraries. For more on that story, see page 81 of this issue.
Editor \& publisher: Mary Ellen K. Davis

Assistant editor: Pam Spiegel

Classified ads manager: Jack Helbig

Editorial assistant: Hugh Thompson/Gregg Opelka

Product sales manager: Stu Foster

CERL News Editorial Board: Pamela Snelson, Willis Hubbard, Irene Hoffman, Robert S. Martin, Zenaida Fernandez; Ex officio: Karen Seibert (ACRL Publications Committee); Gloriana St. Clair (CGRL editor); Anne Beaubien (ACRL past-presiclent).

Editorial offices: (312) 280-2511

E-mail: U38398@UICVM.vic.edu

CERL New's Fax: (312) 280-7663;

ACRI fax: (312) 280-2520

Product advertising: Contact Stu Foster, ACRL Advertising, c/o Choice, 100 Riverview Center, Middletown, CT 06457 (203) 347-3764

Classified advertising: Contact Jack Helbig, CGRL News, 50 E. Huron St., Chicago, 1L 60611; (312) 280-2513; E-mail: U21808@uicum.uic.edu.

Production office: 50 E, liuron St., Chicago, IL 60611-2795.

Circulation office: Change of address and subscriprion or ders should be addressed to College \& Research Libraries News, c/o CHOICE Subscriptions, attn: Steven Conforti, 100 Riverview Center, Middletown, CT 06457-3445. Phone (203) 347-6933; fax: (203) 346-8586. Allow eight weeks for new subscriptions

College \& Researcb Libraries News (ISSN 0099-0086) is published by the Association of College \& Research Librar ies, a division of the American Library Association. as 11 monthly (combining July/August) issues, at $50 \mathrm{E}$. Huron St. Chicago, IL 6061 1-2795. Inclusion of an article or an advertisement in CERI Neu's does not constitute official endorsement by ACRL or ALA.

Indexed in Current Contents. Social \& Behavioral Sciences Current Index to Journals in Education: Information Science Abstracts; Library E Information Science Abstracts; $L i$ brary Literature; and Social Sciences Citation Index.

Annual subscription: For members of ACRL, $\$ 12.50$ per year, included in membership dues; for non-members, $\$ 30.00$ per year in U.S., $\$ 35.00$ per year in Canada and other PUAS countries, $\$ 40.00$ in other foreign countries. Single copies and back issues: $\$ 6.50$ each. Second-class postage paid for at Chicago, Illinois, and at additional mailing offices

TO THE POSTMASTFR: iend address changes to College $E R$ Rsearch Libraries Neus, c/o CHOICE Subscriptions, attn: Steven Confort, 100 Riverview Center, Middletown, CT 06457-3445.

(c) American Library Association 1994. All material in this joumal subject to copyright by the American Library Association may be photocopied for the noncommercial purpose of scientific or educational advancement.

CERL News is published on recycled, acid-free paper. ACRI. Board of Directors: President-Thomas G. Kirk; president-elect-Susan K. Martin; past-president-Jacquelyn McCoy; councillor-Rochelle Sager; Budget \& Finance Com. rep.-Thomas Peischl; directors_Karin Begg Borei. Rosemary Henderson, Frances J. Maloy, Ray E. Metz, Linda L. Phillips, Shelley E. Phipps, Barbara J. Winkopf; Planning Com. chairSandra Ready; ACRL Executive Director-Althea H. Jenkins. 


\section{In the News}

"Empowering Afro-American Organizations: Present and Future" is the theme of the February 1994 Afro-American History Month according to Chase's Annual Events 1994. In this issue we bring this observance period (variously designated as Negro History, Black History, Afro-American History, Black Heritage, and Black Expressions) to your attention with a number of special items.

Our cover features Mary McLeod Bethune (1875-1955), an African American activist who, among her many contributions, founded the Daytona Literary and Industrial School for Training Negro Girls (now Bethune-Cookman College in Daytona Beach, Florida), and served as its president from 1904-1942 and 1946-1947

Our Internet resource list this month, compiled by Patricia Kuntz, features resources for African studies and even includes information about network linkages in Africa. Grace Jackson-Brown gives us an overview of three special collections in the humanities at Indiana University with emphasis on the history and culture of African Americans.
February is also the month to plan your National Library Week observance. ALA President Hardy Franklin asks for your participation in an ALA-sponsored customer service satisfaction survey. Linda Wallace, director of ALA's Public Information Office, gives us the how-to survey information and a camera-ready survey (see page 65) to use with your library.

Getting a handle on the ever-changing Internet resources "is a lot like browsing a used book store; amidst the dust piles of junk once in a while you come across a gem," according to Sara Amato. Amato, the systems librarian at Willamette University, is the editor of a new CERL News column, "Internet Reviews," which will feature critical, signed reviews of selected Internet resources. We hope this column will help you find those Internet gems. Amato is looking for reviewers (details are given in her column on page 89) so please do contact her.

-Mary Ellen K. Davis Editor \& Publisher U3839@uicvm.uic.edu

\section{Access, Ownership, and Resource Sharing Norman, Oklahoma March 3 - 4, 1994}

Speakers:

Charles Hamaker - Louisiana State University

Bonnic Juergens - Amigos Bibliographic Council

Kit Kennedy - Readmore Academic Services

Frederick Lynden - Brown University

Genevieve Owens - University of Missouri-St. Louis

John Secor - Yankee Book Peddler

Thomas Shaughnessy - University of Minnesota-Twin Cities

Donald Simpson - Center for Research Libraries

Contact for Information: Donald C. Hudson, University of Oklahoma Libraries, Norman, OK 73019-0528 Phone: 405-325-2611 